\title{
Genomic Landscape of Hodgkin Lymphoma
}

\author{
Magdalena M. Brune, Darius Juskevicius, Jasmin Haslbauer, Stefan Dirnhofer and Alexandar Tzankov * \\ Institute of Medical Genetics and Pathology, University Hospital Basel, Schönbeinstrasse 40, \\ CH 4031 Basel, Switzerland; magdalena.brune@usb.ch (M.M.B.); darius.juskevicius@usb.ch (D.J.); \\ jasmindionne.haslbauer@usb.ch (J.H.); stefan.dirnhofer@usb.ch (S.D.) \\ * Correspondence: alexandar.tzankov@usb.ch; Tel.: +41-61-265-2757
}

check for

updates

Citation: Brune, M.M.; Juskevicius, D.; Haslbauer, J.; Dirnhofer, S.; Tzankov, A. Genomic Landscape of Hodgkin Lymphoma. Cancers 2021, 13, 682. https://doi.org/10.3390/ cancers 13040682

Academic Editor: Massimo Mascolo Received: 5 January 2021

Accepted: 4 February 2021

Published: 8 February 2021

Publisher's Note: MDPI stays neutral with regard to jurisdictional claims in published maps and institutional affiliations.

Copyright: (c) 2021 by the authors. Licensee MDPI, Basel, Switzerland. This article is an open access article distributed under the terms and conditions of the Creative Commons Attribution (CC BY) license (https:// creativecommons.org/licenses/by/ $4.0 /)$.
Simple Summary: Hodgkin lymphoma (HL) is composed of many reactive and only a few cancer cells, so-called Hodgkin and Reed-Sternberg (HRS) or lymphocyte predominant (LP) cells. Due to the scarcity of these cells, it was difficult to perform high-throughput molecular investigations on them for a long time. With the help of recently developed methods, it is now possible to analyze their genomes. This review summarizes the genetic alterations found in HRS and LP cells that impact immune evasion, proliferation and circumvention of programmed cell death in HL. Understanding these underlying molecular mechanisms is essential, as they may be of prognostic and predictive value and help to improve the therapy especially for patients with recurrent or treatment-resistant disease.

Abstract: Background: Hodgkin lymphoma (HL) is predominantly composed of reactive, non-neoplastic cells surrounding scarcely distributed tumor cells, that is, so-called Hodgkin and Reed-Sternberg (HRS) or lymphocyte predominant (LP) cells. This scarcity impeded the analysis of the tumor cell genomes for a long time, but recently developed methods (especially laser capture microdissection, flow cytometry/fluorescence-activated cell sorting) facilitated molecular investigation, elucidating the pathophysiological principles of "Hodgkin lymphomagenesis". Methods: We reviewed the relevant literature of the last three decades focusing on the genomic landscape of classic and nodular lymphocyte predominant HL (NLPHL) and summarized molecular cornerstones. Results: Firstly, the malignant cells of HL evade the immune system by altered expression of PDL1/2, B2M and MHC class I and II due to various genetic alterations. Secondly, tumor growth is promoted by permanently activated JAK/STAT signaling due to pervasive mutations of multiple genes involved in the pathway. Thirdly, apoptosis of neoplastic cells is prevented by alterations of NF- $\mathrm{KB}$ compounds and the PI3K/AKT/mTOR axis. Additionally, Epstein-Barr virus infection can simultaneously activate JAK/STAT and NF- $\mathrm{B}$, similarly leading to enhanced survival and evasion of apoptosis. Finally, epigenetic phenomena such as promoter hypermethylation lead to the downregulation of B-lineage-specific, tumor-suppressor and immune regulation genes. Conclusion: The blueprint of HL genomics has been laid, paving the way for future investigations into its complex pathophysiology.

Keywords: Hodgkin lymphoma; cell lines; cell enrichment; 9p24 locus; JAK/STAT; NF-kB; PDL1; PDL2; PI3K/AKT/mTOR; Epstein-Barr virus; mutations; genomes; epigenetics

\section{Introduction: Searching and Finding the Needle in the Haystack}

Hodgkin lymphoma (HL) is unique in many aspects. In contrast to many other malignant tumors, HL not only escapes immunologic control but uses and recruits the immune system for its purposes, which leads to a significant and heterogeneous tumor microenvironment. Indeed, malignant lymphocyte predominant (LP) cells in nodular lymphocyte predominant HL (NLPHL), as well as Hodgkin and Reed-Sternberg (HRS) cells in classic HL (cHL), represent only a minor component (typically less than 1\%) of the affected tissues. Investigation of these scarce neoplastic cells, therefore, resembles the search of the needle in the haystack, substantially impeding the analysis of the respective tumor cell genomes, as high-throughput molecular research methods require high tumor 
cell purity and substantial input DNA content. However, recent developments in the field may facilitate the study of HL genomics.

Much insight into the genetics of HL has been gained through the investigation of cell lines, making the application of, for example, whole-exome sequencing possible [1]. However, the validity of these investigations is limited as they are not representative of the complex intratumoral heterogeneity in HL. Particularly in cHL, almost all cell lines derive from refractory and relapsing cases, by no means reflecting the great majority of clinical courses [2]. Furthermore, there is only one existing NLPHL cell line (DEV) and some bona fide HL cell lines that have been misidentified as such [3,4]. In contrast, laser capture microdissection (LCM) of neoplastic LP and HRS cells from affected tissues represents a more realistic approach and, until very recently, has been the most widely used method in genetic studies of cHL. With the help of this technique, recurrent genomic gains and losses, as well as mutations of single candidate genes, have been identified (e.g., [5,6]). Nevertheless, LCM has important disadvantages that limit its use. Apart from being highly labor-intensive, this method involves high-energy laser radiation, potentially leading to DNA damage. Furthermore, tumor cells are collected out of tissue slides, which contain truncated nuclei possibly leading to impaired assay quality [7]. An alternative method using flow cytometry, enabling rapid isolation and high purification of HRS cells out of fresh or frozen tissue samples was introduced by Fromm et al. [8]. Based on this protocol, the first whole-exome sequencing study of HRS cells was performed in 2015 [9]. In 2018, our group developed a novel fluorescence-activated cell sorting (FACS)-based enrichment technique for the isolation of HRS cells out of formalin-fixed and paraffin-embedded (FFPE) archival tissues [7]. This involves DNA enrichment followed by whole-genome amplification and the application of a customized lymphoma panel assay of 68 genes [10]. Although the enrichment of tens of thousands of tumor cells is possible without potential laser radiationinduced DNA damage, the preservation of sufficient tissue antigenicity and cytometric recognition of specific signals remain obstacles in FFPE [7,11]. Another promising and elegant approach is the analysis of circulating tumor DNA (ctDNA) of patients with cHL as reported by Spina et al. [12] and most recently by Desch et al. for pediatric HL patients [13]. This capture-based technology can noninvasively detect mutations in HRS cells, tracking their clonal evolution in the course of therapy as well as monitoring minimal residual disease.

With the help of these methods, a general framework of the cellular pathways and genetic alterations of HL have been elucidated in the last three decades. In 1994, the B-cell lineage origin of HRS cells was identified by demonstrating clonally rearranged immunoglobulin heavy- and light-chain $(I G)$ genes bearing crippling mutations [14]. Under physiological circumstances, B-cells bearing such mutations would rapidly be eliminated by apoptosis. Thus, in order to undermine apoptosis-inducing mechanisms, HRS cells manipulate key cellular signaling pathways (mainly JAK/STAT and NF- $\mathrm{kB}$ ), introducing a multitude of salvage pathways (immune evasion and infection/reactivation of Epstein Barr virus (EBV)) as well as promoter hypermethylation of genes (e.g., [15-19]). Thus, multipleaptly called pervasive mutations have been identified in HL $[11,16]$. In the next sections, known genomic aberrations in HL will be discussed in the light of affected pathways (Figure 1). 


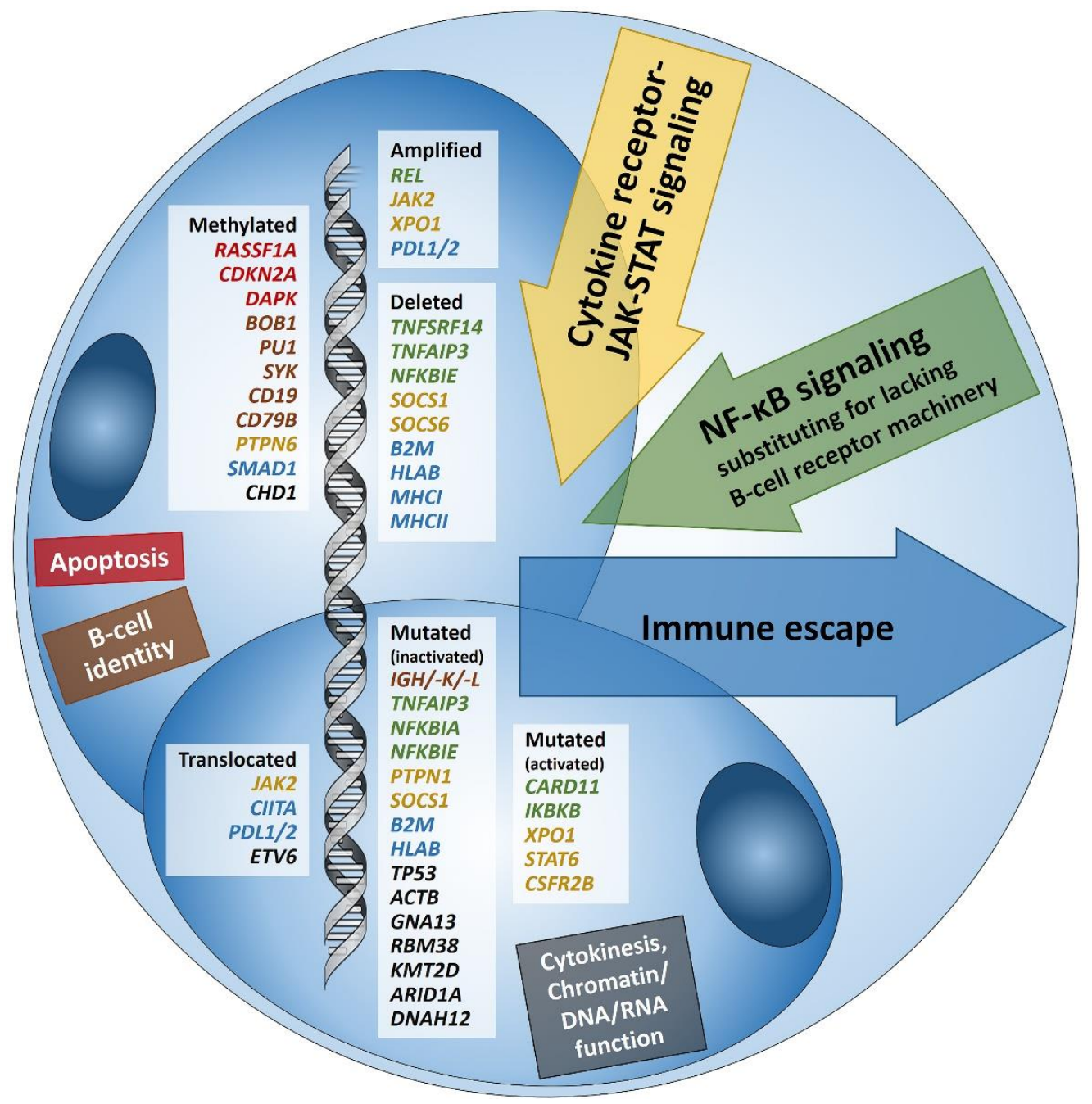

Figure 1. Summary of known genetic aberrations in classic Hodgkin lymphoma (cHL) arranged according to aberration type and color-coded according to the affected cellular process that they dysregulate in Hodgkin and Reed-Sternberg cells; genes encoding for proteins related to apoptosis are in red, to B-cell identity - in brown, to cytokine (mainly JAK-STAT) signaling -in orange, to NF- $\mathrm{KB}$ signaling — in green, to immune escape - in blue, and to cytokinesis, chromatin/DNA/RNA functions-in black; inactivating translocations of SOCS1 that are characteristic of pediatric cHL [13] are not sown.

\section{Immune Evasion}

Several genes involved in the development of hematolymphoid malignancies are located at the 9p24 locus. This includes key targets of immune checkpoint inhibition such as programmed death ligands 1 and 2 (PDL1/PDL2), which evokes potential therapeutic interest (rev. in [20] and in other contributions within this special issue). Most investigated cases of $\mathrm{cHL}$ show genetic alterations of PDL1/2, most commonly copy number gains and amplifications (up to 55\% and 35\%, respectively) [15]. In cHL-mainly the nodular sclerosis subtype-these copy number gains were found to correlate with higher expression of PDL1 as determined by immunohistochemistry (Figure 2A). They represent the hallmark of tumor-induced immune modulation mainly impeding effector T-cell proliferation and activation as well as stimulating immunosuppressive regulatory T-cells [15,20-22]. In a minority of cases, structural abnormalities of 9p24 have been found in CHL (Figure 2B, insert), leading to translocations of PDL1/2 to several partners [23]. Single nucleotide mutations, insertions and deletions of $P D L 1 / 2$ are not (yet) found to play a major role in lymphomagenesis [20]. 

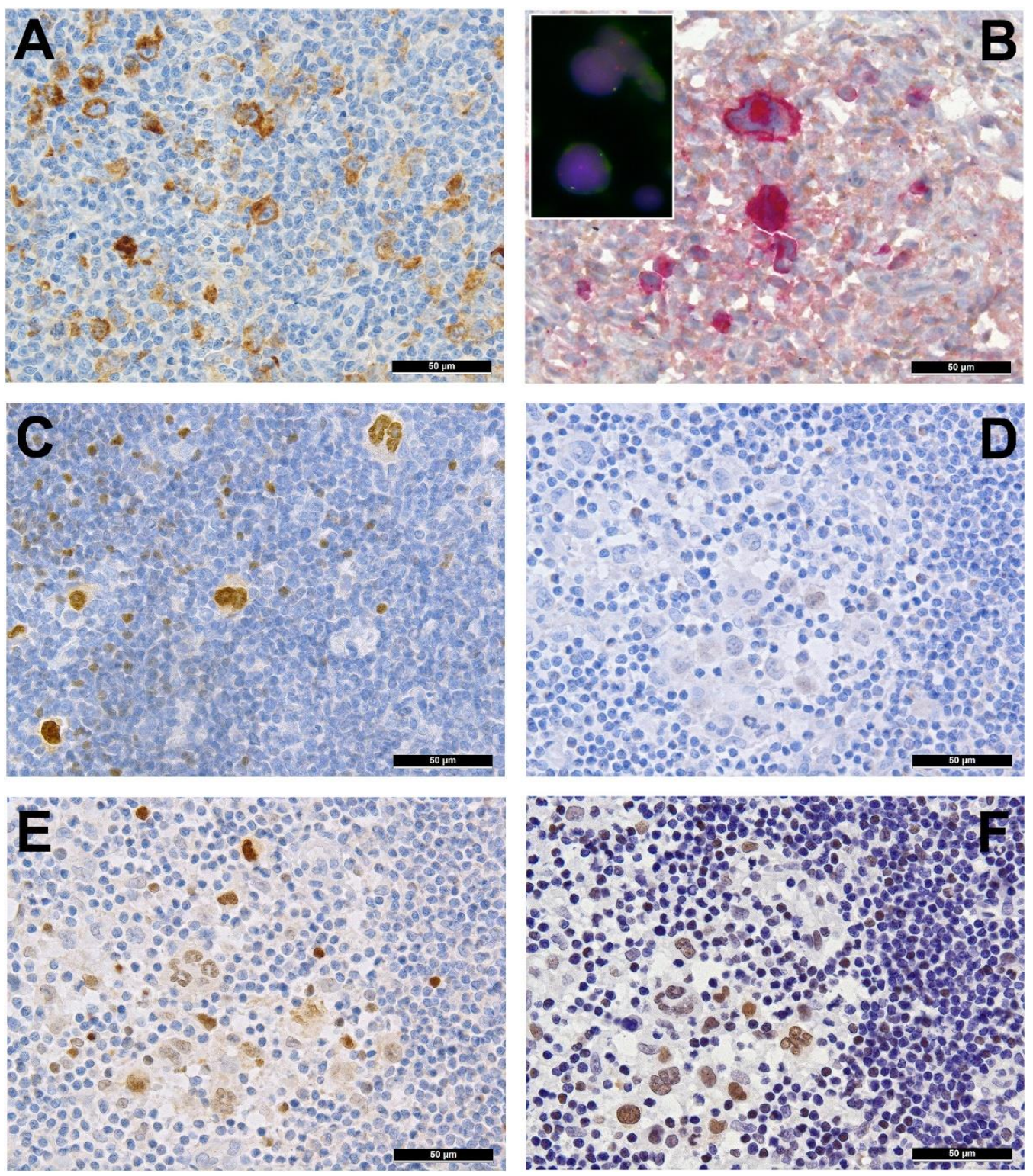

Figure 2. (A) PDL1 overexpressing Hodgkin and Reed-Sternberg (HRS) cells in a case of PDL1/2 amplified classic Hodgkin lymphoma (cHL). (B) HRS cells expressing phosphorylated (p) JAK2 in a $J A K 2$ rearranged cHL (insert with split red and green FISH signals corresponding to the rearranged allele and one fused yellow signal corresponding to the wild type allele of the JAK2 gene in the respective large HRS cell-equivalents utilizing a break-apart JAK2 probe). (C) pSTAT6 overexpressing HRS cells in a case of STAT6-mutated cHL. (D) Expression of pSTAT6 only in a few HRS cells as compared to. (E) pSTAT5 and, particularly, pSTAT3. (F) in a case of SOCS1-mutated cHL.

Importantly, 9p24 alterations, especially copy number gains, were associated with inferior outcome in conventionally treated patients [15] but were an indicator for response and superior progression-free survival-to PD1/PDL1 immune checkpoint inhibitionbased immunotherapy [24]. Along with very convincing results of a prospective trial with nivolumab in relapsed or refractory $\mathrm{cHL}$ [25], this was founding for treatment advances in such instances as nicely reviewed [26], and may lead to first-line therapy paradigm changes in cHL. Furthermore, a very recent work highlighted the importance of a broad baseline T-cell repertoire for successful immune-checkpoint inhibitor treatment, being most effective in patients with therapy-associated diversity increase in the $\mathrm{CD} 4^{+}$compartment and in those with an abundance of activated natural killer cells and a newly identified 
$\mathrm{CD}^{-} \mathrm{CD}^{+} 8^{+} \mathrm{CD}^{+} \mathrm{GrB}^{+}$subset of innate immune cells, which may function as direct cytotoxic effectors in even the absence of major histocompatibility complex (MHC) class I (the latter being characteristic of cHL; see below) [27].

Inactivating mutations of the beta 2 microglobulin gene $(B 2 M)$ also play an instrumental role in immune evasion, influencing the assembly of MHC class I and thus altering tumor cell "visibility" for effector cells [1]. Indeed, B2M is the most commonly mutated or deleted gene in up to $70 \%$ of studied cHL cases $[9,11]$. Furthermore, its deficiency is associated with the nodular sclerosis subtype, pointing towards its potential influence on the tumor microenvironment $[7,9,16]$. Wienand et al. additionally detected mutations or deletions of $H L A-B$ in approximately $15 \%$ of $\mathrm{cHL}$, representing another potential mechanism of MHC class I assembly dysregulation. Moreover, the MHCI (and MHCII) loci at 6p21 are among the commonly deleted in cHL $[5,7,11]$. Interestingly, a decrease of MHC class I expression is associated with inferior clinical outcome after standard chemotherapy, but not immune-checkpoint inhibition. To be comprehensive, Epstein-Barr virus (EBV) positive cHL have significantly higher MHC class I expression on HRS cells than EBV-negative cases $[11,28]$. In contrast to MHC class I, the expression of MHC class II is predictive for response to PD1-blockade in cHL [24], fitting well with the above-mentioned observations on the central role of immune responses linked to the $\mathrm{CD}^{+}$cellular compartment.

Finally, the MHC class II transactivator CIITA has been identified to be involved in a gene fusion in $\mathrm{cHL}$ cell lines and in $15 \%$ of investigated clinical cases [17]. Genomic aberrations in CIITA result in a downregulation of surface MHC class II expression as well as overexpression of PDL1/PDL2, hampering anti-tumor immune response.

A complex network of cytokines and chemokines secreted by both malignant and reactive cells orchestrates the interaction between HRS and LP cells, respectively, and the surrounding microenvironment [29]. One component of this network is the immunosuppressive effect of transforming growth factor-beta (TGF- $\beta$ ) on tumor-infiltrating lymphocytes. Until recently, it was unclear why HRS and LP cells remain unaffected by the anti-neoplastic properties of TGF- $\beta$. Previous studies on diffuse large B-cell lymphoma (DLBCL) revealed SMAD1 as a key messenger in the tumor-suppressive signaling axis of TGF- $\beta$ [30]. In concordance with this study, our group was able to show a lack of SMAD1 expression due to hypermethylation of its promoter region in LP and HRS cells of almost all studied clinical cases (14/14 NLPHL cases, 100\% and 138/143 cHL cases, 97\%). Most interestingly, this mechanism was reversible in an affected cell line by treatment with decitabine, a DNA methyltransferase inhibitor [19].

\section{Pervasive JAK/STAT Signaling}

Another gene located at 9p24 is Janus kinase 2 (JAK2), which has gained much attention in the context of myeloproliferative diseases. As $J A K 2$ is localized in close proximity to PDL1/2, it is most often encompassed in amplifications of the 9p24 region [31,32]. JAK2 belongs to a family of cytoplasmic tyrosine kinases that activate its target genes via phosphorylation of signal transducer and activator of transcription (STAT) factors. Furthermore, JAKs are capable of direct chromatin remodeling by histone phosphorylation and are able to activate other intracellular pathways (e.g., AKT) [33]. Although activating point mutations of $J A K 2$, which are common in myeloid neoplasms, are very rarely found in lymphomas, the enhanced activity of the JAK/STAT signaling pathway by 9p24 amplification seems to play an important role in the development of $\mathrm{CHL}$ as our own data and other studies suggest $[16,31]$. The increased gene dosage of $J A K 2$ indeed seems to have a functional effect, as cases with 9p24 amplification show higher amounts of phosphorylated-and thus activated-JAK2 (Figure 2B) and STAT3 [31]. The central importance of the JAK/STAT cascade to HL is reflected by the presence of various alterations of multiple genes encoding multiple members of the pathway. Inactivating mutations, deletions and-especially in pediatric CHL [13]-inactivating translocations of SOCS1 and, rarely, SOCS6, both negative regulators of JAK/STAT signaling, can be found in up to $50 \%$ of NLPHL [34] and $60 \%$ of cHL $[7,11,16,35]$. This consecutively leads to the accumulation of various nuclear STATs in 
HL (Figure 2D-F). Bona fide activating mutations of the nuclear shuttle protein XPO1 also contribute to the nuclear accumulation of STATs and have been found in $18 \%, 24 \%$ and $26 \%$ of the studied cHL cases, respectively $[11,16,36]$, and patients with the detectable hotspot mutation XPO1 E571K even tended towards a shorter progression-free survival [36]. XPO1 (or CRM1) is responsible for the nucleo-cytoplasmatic transport of more than 200 proteins, among them p53 and phosphorylated STATs [37,38]. Abnormal expression of this now therapeutically targetable protein has been found to worsen the prognosis of DLBCL patients that already display prognostically unfavorable factors such as BCL2 overexpression but also predicts a better response to the clinically available XPO1 inhibitor selinexor in this particular subgroup [39]. Importantly, Tiacci et al. treated cHL cell lines with selinexor, which resulted in growth inhibition and induction of apoptosis in cells with an E571K hotspot mutation [16].

Another commonly affected target is STAT6 (Figure 2C); gains of its coding chromosomal region 12q13 and activating missense mutations are found in approximately $50 \%$ and $40 \%$ of cHL, respectively $[5,7,12,16]$. Importantly, even cooperative mutations in SOCS1 and STATs have been found in CHL [16].

Activating mutations in the cytokine receptor CSF2RB were found to enhance JAK/STAT signaling in up to $20 \%$ of cHL [11]. Other identified genetic alterations impair JAK2 dephosphorylation; these are abrogating mutations and deletions of PTPN1 and promoter hypermethylation of PTPN6 (SHP1) in subsets of cHL [40,41]. Additionally, rare fusions of the JAK2 locus that may lead to constitutively active JAK2 have been described in cHL (e.g., JAK2-SEC31) [31,42].

Most importantly, there seems to be an additive effect of PDL1/2 alterations and the activation of the JAK/STAT signaling pathway: Green et al. demonstrated that JAK2/STAT synergistically enhance PDL1 expression, thus further fueling a vicious circle [22].

The lysine (K)-specific demethylase 4C (KDM4C) gene, also known as JMJDC2, is similarly found at the 9p24 locus. The amplification of this chromatin remodeler has been suggested, in addition, and in synergy to JAK2, to have a pro-oncogenic effect on HL, among others upregulating MYC expression in lymphoma cells [32,43].

\section{Disruption of the NF-KB Pathway}

The binding of the transcription factor NF- $\mathrm{BB}$ enhances cell proliferation and survival and diminishes the effect of proapoptotic signals. Aberrant NF- $k B$ pathway compounds are found in about $50 \%$ of $\mathrm{cHL}$ cases, consistent with the prominent role of NF- $\mathrm{KB}$ signaling in HRS cells. This includes inactivating mutations and deletions of TNFAIP3 coding for A20, one of the key inhibitors of the canonical NF- $\kappa B$ pathway, in up to $44 \%$ of analyzed cell lines and cHL cases, especially of the nodular sclerosis subtype and in pediatric cases $[9,12,13,16,44]$. Additionally, other rare activating mutations of $I K B K B$ and inactivating mutations (rarely deletions) of the inhibitors NFKBIE and NFKBIA have been identified [11-13,16,45-48].

Our own studies [7] and previous findings $[9,49,50]$ revealed gains of the entire short arm of chromosome $2(2 \mathrm{p})$ in approximately $60 \%$ of investigated cHL samples. Amongst other genes, this chromosomal region contains $R E L$, a subunit of the canonical NF- $\mathrm{B}$ pathway. In another $30 \%$ of the cases, $C A R D 11$, another upstream component of the NF- $\mathrm{B}$ pathway, has been found to be mutated in cHL [7].

\section{Alterations in PI3K/AKT/mTOR Pathway and Impairment of Cytokinesis}

The PI3K/AKT/mTOR pathway is one of the key cell cycle regulators. It is an important target for alterations in cancer cells leading to a net effect of uncontrolled proliferation and decreased apoptosis [51]. Perturbations of this signaling cascade have been found in approximately $45 \%$ of cHL [12]. For instance, GNA13, which encodes the G13 protein alpha subunit, a tumor suppressor that inhibits AKT phosphorylation and helps to control proliferating germinal center B cells [16] is a recurrent target (25\%) of mutations in cHL $[11,13,16]$. Inactivating mutations encompass missense, nonsense, as well as frameshift mutations, and are tightly associated with STAT6 alterations. Inactivation of 
GNA13 results in decreased apoptosis of dysfunctional germinal center B-cells and their spread outside the lymphoid follicle [52]. Aberrations of the PI3K/AKT signaling activity may be linked to inactivating ITPKB mutations, found in slightly over $25 \%$ of cHL [12]. Normally, ITPKB dampens PI3K/AKT signaling by upregulating IP4, a soluble pathway antagonist [53].

Importantly, Hodgkin cells generate multinuclear Reed-Sternberg cells-a cytomorphological hallmark of cHL-due to incomplete cytokinesis [54,55]. Indeed, mutations of GNA13 also result in dysfunctional microtubule dynamics during cytokinesis by interacting with RhoA [56,57]. In addition, during cytokinesis, the DNA-binding protein CDH1 is excluded from the nucleus and is reincorporated during telophase [58]. The identified posttranslational alterations of $C D H 1$ in $\mathrm{CHL}$ may impair this process, leading to impaired cytokinesis [41]. Furthermore, DNAH12, a gene encoding for dynein axonemal heavy chain 12 essential for microtubule motor activity, is frequently mutated in cHL [11].

\section{Other Genetic Aberrations}

TP53 mutations are found in almost $10 \%$ of cHL cases and are associated with a higher number of overall mutations, stressing TP53's role as the "guardian of the genome" [7,16]. One group even identified TP53 to be the most commonly mutated gene in their investigated cHL series with an incidence of slightly over 20\% [59]. Interestingly, a loss of RMB38, an RNA-binding protein that restrains the translation of wild-type p53 mRNA, has been shown to drive lymphomagenesis in murine models via increased mutant TP53 expression and decreased expression of PTEN; truncating and missense mutations of RBM38 have been found in approximately $15 \%$ of investigated cHL [11,60].

Structural variants of ETV6, a commonly rearranged locus in hematological and solid malignancies, were found in just over $15 \%$ of cHL cases [11]. Although the exact oncogenic mechanism by which ETV6 translocations contribute to lymphomagenesis is still to be determined, it is assumed to lead to a loss of ETV6-mediated transcriptional control mechanisms [61].

Another pathway recurrently altered by genomic lesions in HRS cells is NOTCH signaling, found to be cumulatively mutated in up to $20 \%$ of the investigated cases including alterations in SPEN (12.5\%), NOTCH1/2 (2.5\%, respectively) and FBXW7 (7.5\%) [12].

\section{Epstein-Barr Virus}

Approximately $40 \%$ of cHL in Western nations are associated with latent EBV infection and presumed to be reliant on its latent membrane antigen 1 (LMP1) [62,63]. LMP1 can activate NF- $\mathrm{KB}$ and PI3K/AKT/mTOR signaling by simulating an active CD40 receptor $[64,65]$. In addition, PDL1 expression can be induced by LMP1 via the activation of STATs, particularly STAT3, introducing an alternative pathway of immune evasion [66]. In general, adult EBV-positive cHL seems to be less dependent on genetically altered intracellular pathways, showing significantly lower numbers of somatic mutations [11,16], which is not that pronounced in pediatric instances [13]. This is analogous to what has been shown in other EBV-associated B-cell lymphomas, in which EBV infection may "substitute" for mutations of genes encoding for immune escape mechanisms $[67,68]$. Importantly, when corrected for the EBV-status, no correlation was found between histological subtype, mutational burden and mutational types in cHL per se [11,16].

\section{Epigenetics in cHL}

Promoter hypermethylation has previously been identified as the underlying mechanism by which HRS cells downregulate B-lineage-specific genes (Figure 3A) such as PU1, $B O B 1, S Y K, C D 19$ and CD79B [69]. Interestingly, data seems to suggest a pathophysiological link between epigenetics and EBV: the frequency of promoter hypermethylation was-similar to what has been shown for mutations-higher in EBV-negative compared to EBV-positive cases, but could occur in both [41] and, in the latter, has been suggested to be dependent on LMP1 through the activation of DNA-methyltransferases [70]. In addition to 
SMAD1 (see above) (Figure 3B), promoter hypermethylation of seven cancer-related genes has been found in CHL: CDKN2A (77\%), RASSF1A (59\%), CDH1 (51\%), DAPK (45\%), GSTP1 (43\%), SHP1 (also called PTPN6) (38\%) and MGMT (24\%) [41]. These genes are involved in the induction of apoptosis, cytokinesis, chromatin and DNA or RNA functions, which are all known to be perturbed in cHL. Finally, Spina et al. found epigenetic changes, mostly related to mutations of $A R I D 1 A$ and $K M T 2 D$, cumulatively affecting 35\% of patients [12].
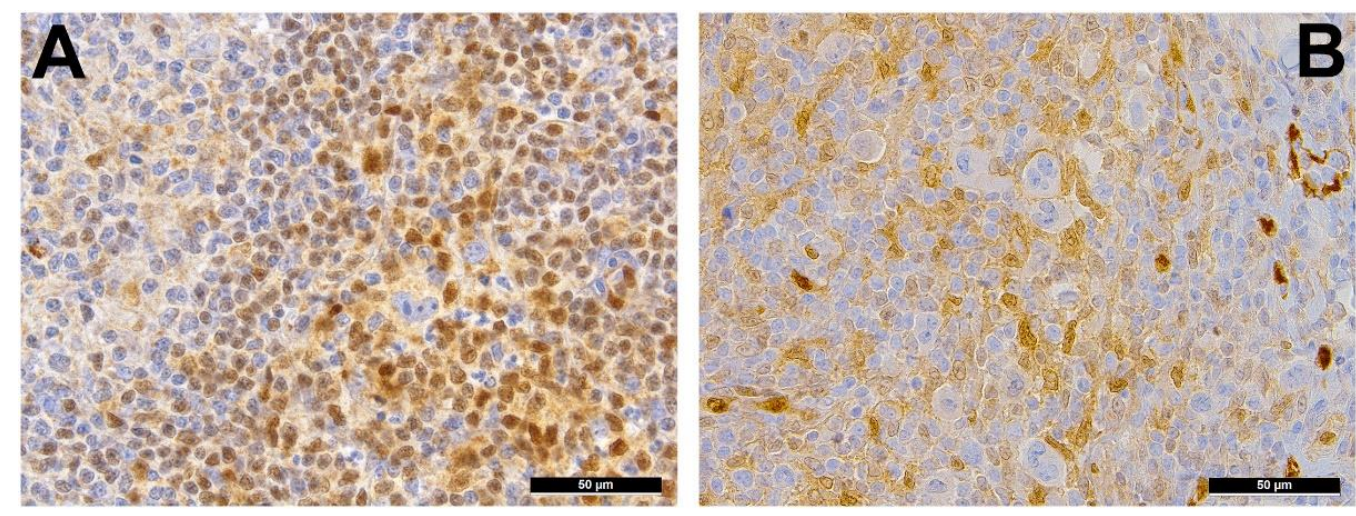

Figure 3. (A) BOB1-negative Reed-Sternberg (RS) cell surrounded by BOB1 positive B-cells; BOB1 inactivation due to promoter hypermethylation of the respective gene in classic Hodgkin lymphoma (cHL). (B) SMAD1 negative RS cells surrounded by SMAD1 positive lymphocytes; SMAD1 is known to be hypermethylated in cHL and nodular lymphocyte-predominant Hodgkin lymphoma.

\section{NLPHL}

Little is known about the genetic landscape of LP cells in NLPHL. They were found to be very closely related to the neoplastic cells in T-cell/histiocyte-rich large B-cell lymphoma, which is clinically a completely different entity [71]. On the other hand, comparisons of the gene expression patterns of LP and HRS cells revealed surprising similarities, as both show constitutive activation of NF- $\mathrm{KB}$ and JAK/STAT signaling (mainly due to mutations of SOCS1) [34,72]. Yet, distinct mutations frequently observed in $\mathrm{CHL}$, such as TNFAIP3 and NFKBIA, seem to be less frequent in NLPHL, while others, such as SGK1, DUSP2 and JUNB, appear to be more common. Genes targeted by somatic hypermutation (a process that is ongoing in NLPHL but to a lesser extent in cHL), such as PAX5, PIM1, RHOH and MYC, are more frequently altered in NLPHL compared to cHL [73-75]. Recently, a recurrent deletion in the chromosomal region 9p11 and translocations affecting BCL6 in a subset of NLPHL have been identified $[72,76,77]$. Both of these aberrations have not been found in $\mathrm{CHL}$.

\section{Conclusions}

In summary, the pathogenesis of HL relies on several important pathophysiological principles. Firstly, immune escape is initiated by altered expression of PDL1/2, B2M, MHC class I and MHC class II. Undermining PDL1/2 signaling and consequently overcoming this immune evasion has become the focus of PD1/PDL1 driven immune checkpoint inhibition studies, as was successfully shown in initial clinical trials for relapsed or refractory HL [25]. Although the prognostic and predictive significance of PDL1 status in HL is not yet fully understood, there is evidence for shorter progression-free survival and an increased incidence of advanced stage disease in patients with 9p24 amplifications [15]. Secondly, constitutively active JAK/STAT signaling as a result of an array of mutations, such as STAT6 and SOCS1, plays a central role in cHL carcinogenesis. Thirdly, members encoding for NF- $\mathrm{KB}$ compounds (and PI3K/AKT/mTOR) are subjected to mutations in HL; these targets typically promote growth and proliferation under physiological conditions but also prevent apoptosis that would eliminate B-cells with crippling IG mutations as observed in HRS cells. Finally, JAK/STAT and NF- $\mathrm{BB}$ can be simultaneously activated by LMP1 in 
EBV-positive cases, eventually leading to PDL1 overexpression, consequently leading to the above-mentioned scenarios.

With the advancement of robust molecular methods enabling investigations of neoplasms with tumor cell paucity, our understanding of the genomic landscape of HL has greatly expanded (Figure 1). The significance of this gained knowledge concerning prognostic and predictive value needs further elucidation. Future investigations should feature larger FFPE cohorts with a particular focus on refractory and relapsed HL.

Author Contributions: Conceptualization, M.M.B. and A.T.; data curation, D.J. and S.D.; writingoriginal draft preparation, M.M.B. and A.T.; writing—review and editing, D.J., J.H. and S.D.; project administration, A.T. All authors have read and agreed to the published version of the manuscript.

Funding: This research received no external funding.

Acknowledgments: The authors dedicate this work to the excellent hematopathologist and friend, Gorana Aralica, who unfortunately and untimely passed away in 2020 at the age of 48.

Conflicts of Interest: The authors declare no conflict of interest.

\section{References}

1. Liu, Y.; Abdul Razak, F.R.; Terpstra, M.; Chan, F.C.; Saber, A.; Nijland, M.; van Imhoff, G.; Visser, L.; Gascoyne, R.; Steidl, C.; et al. The mutational landscape of Hodgkin lymphoma cell lines determined by whole-exome sequencing. Leukemia 2014, 28, $2248-2251$. [CrossRef]

2. Drexler, H.G.; Pommerenke, C.; Eberth, S.; Nagel, S. Hodgkin lymphoma cell lines: To separate the wheat from the chaff. Biol. Chem. 2018, 399, 511-523. [CrossRef]

3. Atayar, C.; Kok, K.; Kluiver, J.; Bosga, A.; van den Berg, E.; van der Vlies, P.; Blokzijl, T.; Harms, G.; Davelaar, I.; Sikkema-Raddatz, B.; et al . BCL6 alternative breakpoint region break and homozygous deletion of 17q24 in the nodular lymphocyte predominance type of Hodgkin's lymphoma-derived cell line DEV. Hum. Pathol. 2006, 37, 675-683. [CrossRef]

4. Drexler, H.G.; Dirks, W.G.; Matsuo, Y.; MacLeod, R.A. False leukemia-lymphoma cell lines: An update on over 500 cell lines. Leukemia 2003, 17, 416-426. [CrossRef]

5. Hartmann, S.; Martin-Subero, J.I.; Gesk, S.; Hüsken, J.; Giefing, M.; Nagel, I.; Riemke, J.; Chott, A.; Klapper, W.; Parrens, M.; et al. Detection of genomic imbalances in microdissected Hodgkin and Reed-Sternberg cells of classical Hodgkin's lymphoma by array-based comparative genomic hybridization. Haematologica 2008, 93, 1318-1326. [CrossRef] [PubMed]

6. Weniger, M.A.; Barth, T.F.; Möller, P. Genomic alterations in Hodgkin's lymphoma. Int. J. Hematol. 2006, 83, 379-384. [CrossRef]

7. Juskevicius, D.; Jucker, D.; Dietsche, T.; Perrina, V.; Rufle, A.; Ruiz, C.; Dirnhofer, S.; Tzankov, A. Novel cell enrichment technique for robust genetic analysis of archival classical Hodgkin lymphoma tissues. Lab. Investig. 2018, 98, 1487-1499. [CrossRef]

8. Fromm, J.R.; Kussick, S.J.; Wood, B.L. Identification and purification of classical Hodgkin cells from lymph nodes by flow cytometry and flow cytometric cell sorting. Am. J. Clin. Pathol. 2006, 126, 764-780. [CrossRef]

9. Reichel, J.; Chadburn, A.; Rubinstein, P.G.; Giulino-Roth, L.; Tam, W.; Liu, Y.; Gaiolla, R.; Eng, K.; Brody, J.; Inghirami, G.; et al. Flow sorting and exome sequencing reveal the oncogenome of primary Hodgkin and Reed-Sternberg cells. Blood 2015, 125, 1061-1072. [CrossRef]

10. Juskevicius, D.; Lorber, T.; Gsponer, J.; Perrina, V.; Ruiz, C.; Stenner-Liewen, F.; Dirnhofer, S.; Tzankov, A. Distinct genetic evolution patterns of relapsing diffuse large B-cell lymphoma revealed by genome-wide copy number aberration and targeted sequencing analysis. Leukemia 2016, 30, 2385-2395. [CrossRef]

11. Wienand, K.; Chapuy, B.; Stewart, C.; Dunford, A.J.; Wu, D.; Kim, J.; Kamburov, A.; Wood, T.R.; Cader, F.Z.; Ducar, M.D.; et al. Genomic analyses of flow-sorted Hodgkin Reed-Sternberg cells reveal complementary mechanisms of immune evasion. Blood Adv. 2019, 3, 4065-4080. [CrossRef]

12. Spina, V.; Bruscaggin, A.; Cuccaro, A.; Martini, M.; Di Trani, M.; Forestieri, G.; Manzoni, M.; Condoluci, A.; Arribas, A.; Terzi-Di-Bergamo, L.; et al. Circulating tumor DNA reveals genetics, clonal evolution, and residual disease in classical Hodgkin lymphoma. Blood 2018, 131, 2413-2425. [CrossRef] [PubMed]

13. Desch, A.K.; Hartung, K.; Botzen, A.; Brobeil, A.; Rummel, M.; Kurch, L.; Georgi, T.; Jox, T.; Bielack, S.; Burdach, S. Genotyping circulating tumor DNA of pediatric Hodgkin lymphoma. Leukemia 2020, 34, 151-166. [CrossRef]

14. Küppers, R.; Rajewsky, K.; Zhao, M.; Simons, G.; Laumann, R.; Fischer, R.; Hansmann, M.L. Hodgkin disease: Hodgkin and Reed-Sternberg cells picked from histological sections show clonal immunoglobulin gene rearrangements and appear to be derived from B cells at various stages of development. Proc. Natl. Acad. Sci. USA 1994, 91, 10962-10966. [CrossRef]

15. Roemer, M.G.; Advani, R.H.; Ligon, A.H.; Natkunam, Y.; Redd, R.A.; Homer, H.; Connelly, C.F.; Sun, H.H.; Daadi, S.E.; Freeman, G.J.; et al. PD-L1 and PD-L2 Genetic Alterations Define Classical Hodgkin Lymphoma and Predict Outcome. J. Clin. Oncol. 2016, 34, 2690-2697. [CrossRef] [PubMed] 
16. Tiacci, E.; Ladewig, E.M.; Schiavoni, G.; Penson, A.; Fortini, E.; Pettirossi, V.; Wang, Y.; Rosseto, A.; Venanzi, A.; Vlasevska, S.; et al. Pervasive mutations of JAK-STAT pathway genes in classical Hodgkin lymphoma. Blood 2018, 131, 2454-2465. [CrossRef] [PubMed]

17. Steidl, C.; Shah, S.P.; Woolcock, B.W.; Rui, L.; Kawahara, M.; Farinha, P.; Johnson, N.A.; Zhao, Y.; Telenius, A.; Neriah, S.B.; et al. MHC class II transactivator CIITA is a recurrent gene fusion partner in lymphoid cancers. Nature 2011, 471, 377-381. [CrossRef] [PubMed]

18. Kilger, E.; Kieser, A.; Baumann, M.; Hammerschmidt, W. Epstein-Barr virus-mediated B-cell proliferation is dependent upon latent membrane protein 1, which simulates an activated CD40 receptor. EMBO J. 1998, 17, 1700-1709. [CrossRef]

19. Gerlach, M.M.; Stelling-Germani, A.; Wu, C.T.; Newrzela, S.; Döring, C.; Vela, V.; Müller, A.; Hartmann, S.; Tzankov, A. SMAD1 promoter hypermethylation and lack of SMAD1 expression in Hodgkin lymphoma: A potential target for hypomethylating drug therapy. Haematologica 2021, 106, 619-621. [CrossRef]

20. Menter, T.; Tzankov, A. Genetic alterations of 9p24 in lymphomas and their impact for cancer (immuno-)therapy. Virchows Arch 2019, 474, 497-509. [CrossRef]

21. Francisco, L.M.; Salinas, V.H.; Brown, K.E.; Vanguri, V.K.; Freeman, G.J.; Kuchroo, V.K.; Sharpe, A.H. PD-L1 regulates the development, maintenance, and function of induced regulatory T cells. J. Exp. Med. 2009, 206, 3015-3029. [CrossRef] [PubMed]

22. Green, M.R.; Monti, S.; Rodig, S.J.; Juszczynski, P.; Currie, T.; O’Donnell, E.; Chapuy, B.; Takeyama, K.; Neuberg, D.; Golub, T.R.; et al. Integrative analysis reveals selective 9p24.1 amplification, increased PD-1 ligand expression, and further induction via JAK2 in nodular sclerosing Hodgkin lymphoma and primary mediastinal large B-cell lymphoma. Blood 2010, 116, 3268-3277. [CrossRef]

23. van Roosbroeck, K.; Ferreiro, J.F.; Tousseyn, T.; van der Krogt, J.A.; Michaux, L.; Pienkowska-Grela, B.; Theate, I.; De Paepe, P.; Dierickx, D.; Doyen, C.; et al. Genomic alterations of the JAK2 and PDL loci occur in a broad spectrum of lymphoid malignancies. Genes Chromosomes Cancer 2016, 55, 428-441. [CrossRef]

24. Roemer, M.G.M.; Redd, R.A.; Cader, F.Z.; Pak, C.J.; Abdelrahman, S.; Ouyang, J.; Sasse, S.; Younes, A.; Fanale, M.; Santoro, A.; et al. Major Histocompatibility Complex Class II and Programmed Death Ligand 1 Expression Predict Outcome After Programmed Death 1 Blockade in Classic Hodgkin Lymphoma. J. Clin. Oncol. 2018, 36, 942-950. [CrossRef] [PubMed]

25. Ansell, S.M.; Lesokhin, A.M.; Borrello, I.; Halwani, A.; Scott, E.C.; Gutierrez, M.; Schuster, S.J.; Millenson, M.M.; Cattry, D.; Freeman, G.J.; et al. PD-1 blockade with nivolumab in relapsed or refractory Hodgkin's lymphoma. N. Engl. J. Med. 2015, 372, 311-319. [CrossRef]

26. Voorhees, T.J.; Beaven, A.W. Therapeutic updates for relapsed and refractory classical Hodgkin lymphoma. Cancers 2020, $12,2887$. [CrossRef] [PubMed]

27. Cader, F.Z.; Hu, X.; Goh, W.L.; Wienand, K.; Ouyang, J.; Mandato, E.; Redd, R.; Lawton, L.N.; Chen, P.H.; Weirather, J.L.; et al. A peripheral immune signature of responsiveness to PD-1 blockade in patients with classical Hodgkin lymphoma. Nat. Med. 2020, 26, 1468-1479. [CrossRef]

28. Roemer, M.G.M.; Advani, R.H.; Redd, R.A.; Pinkus, G.S.; Natkunam, Y.; Ligon, A.H.; Connelly, C.F.; Pak, C.J.; Carey, C.D.; Daadi, S.E.; et al. Classical Hodgkin Lymphoma with Reduced $\beta 2 \mathrm{M} / \mathrm{MHC}$ Class I Expression Is Associated with Inferior Outcome Independent of 9p24.1 Status. Cancer Immunol. Res. 2016, 4, 910-916. [CrossRef]

29. Nagpal, P.; Descalzi-Montoya, D.B.; Lodhi, N. The circuitry of the tumor microenvironment in adult and pediatric Hodgkin lymphoma: Cellular composition, cytokine profile, EBV, and exosomes. Cancer Rep. (Hoboken) 2020. ahead of print. [CrossRef]

30. Stelling, A.; Wu, C.T.; Bertram, K.; Hashwah, H.; Theocharides, A.; Manz, M.G.; Tzankov, A.; Müller, A. Pharmacological DNA demethylation restores SMAD1 expression and tumor suppressive signaling in diffuse large B-cell lymphoma. Blood Adv. 2019, 3, 3020-3032. [CrossRef]

31. Meier, C.; Hoeller, S.; Bourgau, C.; Hirschmann, P.; Schwaller, J.; Went, P.; Pileri, S.A.; Reiter, A.; Dirnhofer, S.; Tzankov, A. Recurrent numerical aberrations of JAK2 and deregulation of the JAK2-STAT cascade in lymphomas. Mod. Pathol. 2009, 22, 476-487. [CrossRef]

32. Rui, L.; Emre, N.C.; Kruhlak, M.J.; Chung, H.J.; Steidl, C.; Slack, G.; Wright, G.W.; Lenz, G.; Ngo, V.N.; Shaffer, A.L.; et al. Cooperative epigenetic modulation by cancer amplicon genes. Cancer Cell 2010, 18, 590-605. [CrossRef] [PubMed]

33. Shi, S.; Calhoun, H.C.; Xia, F.; Li, J.; Le, L.; Li, W.X. JAK signaling globally counteracts heterochromatic gene silencing. Nat. Genet. 2006, 38, 1071-1076. [CrossRef]

34. Mottok, A.; Renné, C.; Willenbrock, K.; Hansmann, M.L.; Bräuninger, A. Somatic hypermutation of SOCS1 in lymphocytepredominant Hodgkin lymphoma is accompanied by high JAK2 expression and activation of STAT6. Blood 2007, 110, 3387-3390. [CrossRef] [PubMed]

35. Weniger, M.A.; Melzner, I.; Menz, C.K.; Wegener, S.; Bucur, A.J.; Dorsch, K.; Mattfeldt, T.; Barth, T.F.; Möller, P. Mutations of the tumor suppressor gene SOCS-1 in classical Hodgkin lymphoma are frequent and associated with nuclear phospho-STAT5 accumulation. Oncogene 2006, 25, 2679-2684. [CrossRef] [PubMed]

36. Camus, V.; Stamatoullas, A.; Mareschal, S.; Viailly, P.J.; Sarafan-Vasseur, N.; Bohers, E.; Dubois, S.; Picquenot, J.M.; Ruminy, P.; Maingonnat, C.; et al. Detection and prognostic value of recurrent exportin 1 mutations in tumor and cell-free circulating DNA of patients with classical Hodgkin lymphoma. Haematologica 2016, 101, 1094-1101. [CrossRef] [PubMed]

37. Stade, K.; Ford, C.S.; Guthrie, C.; Weis, K. Exportin 1 (Crm1p) is an essential nuclear export factor. Cell 1997, 90, 1041-1050. [CrossRef]

38. Azizian, N.G.; Li, Y. XPO1-dependent nuclear export as a target for cancer therapy. J. Hematol. Oncol. 2020, 13, 61. [CrossRef] 
39. Deng, M.; Zhang, M.; Xu-Monette, Z.Y.; Pham, L.V.; Tzankov, A.; Visco, C.; Fang, X.; Bhagat, G.; Zhu, F.; Dybkaer, K.; et al. XPO1 expression worsens the prognosis of unfavorable DLBCL that can be effectively targeted by selinexor in the absence of mutant p53. J. Hematol. Oncol. 2020, 13, 148. [CrossRef]

40. Gunawardana, J.; Chan, F.C.; Telenius, A.; Woolcock, B.; Kridel, R.; Tan, K.L.; Ben-Neriah, S.; Mottok, A.; Lim, R.S.; Boyle, M.; et al. Recurrent somatic mutations of PTPN1 in primary mediastinal B cell lymphoma and Hodgkin lymphoma. Nat. Genet. 2014, 46, 329-335. [CrossRef]

41. Dhiab, M.B.; Ziadi, S.; Mestiri, S.; Gacem, R.B.; Ksiaa, F.; Trimeche, M. DNA methylation patterns in EBV-positive and EBVnegative Hodgkin lymphomas. Cell Oncol. (Dordr.) 2015, 38, 453-462. [CrossRef]

42. van Roosbroeck, K.; Cox, L.; Tousseyn, T.; Lahortiga, I.; Gielen, O.; Cauwelier, B.; De Paepe, P.; Verhoef, G.; Marynen, P.; Vandenberghe, P.; et al. JAK2 rearrangements, including the novel SEC31A-JAK2 fusion, are recurrent in classical Hodgkin lymphoma. Blood 2011, 117, 4056-4064. [CrossRef]

43. Berry, W.L.; Janknecht, R. KDM4/JMJD2 histone demethylases: Epigenetic regulators in cancer cells. Cancer Res. 2013, 73, 2936-2942. [CrossRef]

44. Schmitz, R.; Hansmann, M.L.; Bohle, V.; Martin-Subero, J.I.; Hartmann, S.; Mechtersheimer, G.; Klapper, W.; Vater, I.; Giefing, M.; Gesk, S.; et al. TNFAIP3 (A20) is a tumor suppressor gene in Hodgkin lymphoma and primary mediastinal B cell lymphoma. J. Exp. Med. 2009, 206, 981-989. [CrossRef] [PubMed]

45. Emmerich, F.; Theurich, S.; Hummel, M.; Haeffker, A.; Vry, M.S.; Döhner, K.; Bommert, K.; Stein, H.; Dörken, B. Inactivating I kappa B epsilon mutations in Hodgkin/Reed-Sternberg cells. J. Pathol. 2003, 201, 413-420. [CrossRef] [PubMed]

46. Cabannes, E.; Khan, G.; Aillet, F.; Jarrett, R.F.; Hay, R.T. Mutations in the IkBa gene in Hodgkin's disease suggest a tumour suppressor role for IkappaBalpha. Oncogene 1999, 18, 3063-3070. [CrossRef] [PubMed]

47. Emmerich, F.; Meiser, M.; Hummel, M.; Demel, G.; Foss, H.D.; Jundt, F.; Mathas, S.; Krappmann, D.; Scheidereit, C.; Stein, H.; et al. Overexpression of I kappa B alpha without inhibition of NF-kappaB activity and mutations in the I kappa B alpha gene in Reed-Sternberg cells. Blood 1999, 94, 3129-3134. [CrossRef]

48. Jungnickel, B.; Staratschek-Jox, A.; Bräuninger, A.; Spieker, T.; Wolf, J.; Diehl, V.; Hansmann, M.L.; Rajewsky, K.; Küppers, R. Clonal deleterious mutations in the IkappaBalpha gene in the malignant cells in Hodgkin's lymphoma. J. Exp. Med. 2000, 191, 395-402. [CrossRef]

49. Joos, S.; Menz, C.K.; Wrobel, G.; Siebert, R.; Gesk, S.; Ohl, S.; Mechtersheimer, G.; Trümper, L.; Möller, P.; Lichter, P.; et al. Classical Hodgkin lymphoma is characterized by recurrent copy number gains of the short arm of chromosome 2. Blood 2002, 99, 1381-1387. [CrossRef]

50. Martín-Subero, J.I.; Gesk, S.; Harder, L.; Sonoki, T.; Tucker, P.W.; Schlegelberger, B.; Grote, W.; Novo, F.J.; Calasanz, M.J.; Hansmann, M.L.; et al. Recurrent involvement of the REL and BCL11A loci in classical Hodgkin lymphoma. Blood 2002, 99, 1474-1477. [CrossRef]

51. Meadows, S.A.; Vega, F.; Kashishian, A.; Johnson, D.; Diehl, V.; Miller, L.L.; Younes, A.; Lannutti, B.J. PI3K $\delta$ inhibitor, GS-1101 (CAL-101), attenuates pathway signaling, induces apoptosis, and overcomes signals from the microenvironment in cellular models of Hodgkin lymphoma. Blood 2012, 119, 1897-1900. [CrossRef]

52. Healy, J.A.; Nugent, A.; Rempel, R.E.; Moffitt, A.B.; Davis, N.S.; Jiang, X.; Shingleton, J.R.; Zhang, J.; Love, C.; Datta, J.; et al. GNA13 loss in germinal center B cells leads to impaired apoptosis and promotes lymphoma in vivo. Blood 2016, 127, $2723-2731$. [CrossRef] [PubMed]

53. Westernberg, L.; Conche, C.; Huang, Y.H.; Rigaud, S.; Deng, Y.; Siegemund, S.; Mukherjee, S.; Nosaka, L.; Das, J.; Sauer, K. Non-canonical antagonism of PI3K by the kinase Itpkb delays thymocyte $\beta$-selection and renders it Notch-dependent. Elife 2016, 5, e10786. [CrossRef]

54. Rengstl, B.; Newrzela, S.; Heinrich, T.; Weiser, C.; Thalheimer, F.B.; Schmid, F.; Warner, K.; Hartmann, S.; Schroeder, T.; Küppers, R.; et al . Incomplete cytokinesis and re-fusion of small mononucleated Hodgkin cells lead to giant multinucleated Reed-Sternberg cells. Proc. Natl. Acad. Sci. USA 2013, 110, 20729-20734. [CrossRef] [PubMed]

55. Nakashima, M.; Ishii, Y.; Watanabe, M.; Togano, T.; Umezawa, K.; Higashihara, M.; Watanabe, T.; Horie, R. The side population, as a precursor of Hodgkin and Reed-Sternberg cells and a target for nuclear factor- $\mathrm{kB}$ inhibitors in Hodgkin's lymphoma. Cancer Sci. 2010, 101, 2490-2496. [CrossRef]

56. Neves, S.R.; Ram, P.T.; Iyengar, R. G protein pathways. Science 2002, 296, 1636-1639. [CrossRef]

57. Weber-Matthiesen, K.; Deerberg, J.; Poetsch, M.; Grote, W.; Schlegelberger, B. Numerical chromosome aberrations are presentwithin the CD30C Hodgkin and ReedeSternberg cells in 100\% ofanalyzed cases of Hodgkin's disease. Blood 1995, 86, 1464-1468. [CrossRef] [PubMed]

58. Stokes, D.G.; Perry, R.P. DNA-binding and chromatin localization properties of CHD1. Mol. Cell. Biol. 1995, 15, $2745-2753$. [CrossRef]

59. Liang, W.S.; Vergilio, J.A.; Salhia, B.; Huang, H.J.; Oki, Y.; Garrido-Laguna, I.; Park, H.; Westin, J.R.; Meric-Bernstam, F.; Fabrizio, D.; et al. Comprehensive genomic profiling of Hodgkin lymphoma reveals recurrently mutated genes and increased mutation burden. Oncologist 2019, 24, 219-228. [CrossRef] [PubMed]

60. Zhang, J.; Xu, E.; Ren, C.; Yang, H.J.; Zhang, Y.; Sun, W.; Kong, X.; Zhang, W.; Chen, M.; Huang, E.; et al. Genetic ablation of Rbm38 promotes lymphomagenesis in the context of mutant p53 by downregulating PTEN. Cancer Res. 2018, 78, 1511-1521. [CrossRef] 
61. Wang, Q.; Dong, S.; Yao, H.; Wen, L.; Qiu, H.; Qin, L.; Ma, L.; Chen, S. ETV6 mutation in a cohort of 970 patients with hematologic malignancies. Haematologica 2014, 99, e176-e178. [CrossRef] [PubMed]

62. Hannigan, A.; Wilson, J.B. Evaluation of LMP1 of Epstein-Barr virus as a therapeutic target by its inhibition. Mol. Cancer 2010, 9, 184. [CrossRef] [PubMed]

63. Murray, P.G.; Young, L.S. An etiological role for the Epstein-Barr virus in the pathogenesis of classical Hodgkin lymphoma. Blood 2019, 134, 591-596. [CrossRef]

64. Mosialos, G.; Birkenbach, M.; Yalamanchili, R.; VanArsdale, T.; Ware, C.; Kieff, E. The Epstein-Barr virus transforming protein LMP1 engages signaling proteins for the tumor necrosis factor receptor family. Cell 1995, 80, 389-399. [CrossRef]

65. Mathas, S.; Hartmann, S.; Küppers, R. Hodgkin lymphoma: Pathology and biology. Semin. Hematol. 2016, 53, 139-147. [CrossRef]

66. Green, M.R.; Rodig, S.; Juszczynski, P.; Ouyang, J.; Sinha, P.; O’Donnell, E.; Neuberg, D.; Shipp, M.A. Constitutive AP-1 activity and EBV infection induce PD-L1 in Hodgkin lymphomas and posttransplant lymphoproliferative disorders: Implications for targeted therapy. Clin. Cancer Res. 2012, 18, 1611-1618. [CrossRef] [PubMed]

67. Menter, T.; Tzankov, A. Mechanisms of immune evasion and immune modulation by lymphoma cells. Front. Oncol. 2018, 8, 54. [CrossRef]

68. Ok, C.Y.; Li, L.; Young, K.H. EBV-driven B-cell lymphoproliferative disorders: From biology, classification and differential diagnosis to clinical management. Exp. Mol. Med. 2015, 47, e132. [CrossRef] [PubMed]

69. Ushmorov, A.; Leithäuser, F.; Sakk, O.; Weinhaüsel, A.; Popov, S.W.; Möller, P.; Wirth, T. Epigenetic processes play a major role in B-cell-specific gene silencing in classical Hodgkin lymphoma. Blood 2006, 107, 2493-2500. [CrossRef]

70. Tsai, C.L.; Li, H.P.; Lu, Y.J.; Hsueh, C.; Liang, Y.; Chen, C.L.; Tsao, S.W.; Tse, K.P.; Yu, J.S.; Chang, Y.S. Activation of DNA methyltransferase 1 by EBV LMP1 Involves c-Jun NH(2)-terminal kinase signaling. Cancer Res. 2006, 66, 11668-11676. [CrossRef]

71. Brune, V.; Tiacci, E.; Pfeil, I.; Döring, C.; Eckerle, S.; van Noesel, C.J.; Klapper, W.; Falini, B.; von Heydebreck, A.; Metzler, D.; et al. Origin and pathogenesis of nodular lymphocyte-predominant Hodgkin lymphoma as revealed by global gene expression analysis. $J$. Exp. Med. 2008, 205, 2251-2268. [CrossRef]

72. Hartmann, S.; Eichenauer, D.A. Nodular lymphocyte predominant Hodgkin lymphoma: Pathology, clinical course and relation to T-cell/histiocyte rich large B-cell lymphoma. Pathology 2020, 52, 142-153. [CrossRef]

73. Liso, A.; Capello, D.; Marafioti, T.; Tiacci, E.; Cerri, M.; Distler, V.; Paulli, M.; Carbone, A.; Delsol, G.; Campo, E.; et al. Aberrant somatic hypermutation in tumor cells of nodular-lymphocyte-predominant and classic Hodgkin lymphoma. Blood 2006, 108, 1013-1020. [CrossRef] [PubMed]

74. Schumacher, M.A.; Schmitz, R.; Brune, V.; Tiacci, E.; Döring, C.; Hansmann, M.L.; Siebert, R.; Küppers, R. Mutations in the genes coding for the NF- $\kappa \mathrm{B}$ regulating factors $\mathrm{I} \kappa \mathrm{B} \alpha$ and A20 are uncommon in nodular lymphocyte-predominant Hodgkin's lymphoma. Haematologica 2010, 95, 153-157. [CrossRef]

75. Hartmann, S.; Schuhmacher, B.; Rausch, T.; Fuller, L.; Döring, C.; Weniger, M.; Lollies, A.; Weiser, C.; Thurner, L.; Rengstl, B.; et al. Highly recurrent mutations of SGK1, DUSP2 and JUNB in nodular lymphocyte predominant Hodgkin lymphoma. Leukemia 2016, 30, 844-853. [CrossRef] [PubMed]

76. Wlodarska, I.; Nooyen, P.; Maes, B.; Martin-Subero, J.I.; Siebert, R.; Pauwels, P.; De Wolf-Peeters, C.; Hagemeijer, A. Frequent occurrence of BCL6 rearrangements in nodular lymphocyte predominance Hodgkin lymphoma but not in classical Hodgkin lymphoma. Blood 2003, 101, 706-710. [CrossRef] [PubMed]

77. Renné, C.; Martín-Subero, J.I.; Hansmann, M.L.; Siebert, R. Molecular cytogenetic analyses of immunoglobulin loci in nodular lymphocyte predominant Hodgkin's lymphoma reveal a recurrent IGH-BCL6 juxtaposition. J. Mol. Diagn. 2005, 7, 352-356. [CrossRef] 